\title{
Low Molecular Weight Hydrogel for Super Efficient Separation of Small Organic Molecules Based on Size Effect
}

Chuanjiang Jian, ${ }^{a \neq}$ Ning Tao, ${ }^{a t}$ Long Xu, ${ }^{b}$ Miaochang Liu, ${ }^{a}$ Xiaobo Huang, ${ }^{a}$ Wenxia Gao ${ }^{a}$ and Huayue $W u^{a}$

a. College of Chemistry and Materials Engineering, Wenzhou University, Chaoyang New Street, Chashan Town, Wenzhou City, Zhejiang Province, 325027, China.

b. School of Material Science and Chemical Engineering, Ningbo University, 818 Fenghua Road, Jiangbei District, Ningbo City, Zhejiang Province, 315211, China.

†These authors contributed equally.

\section{Corresponding Author}

*E-mail: wenxiag@wzu.edu.cn. Phone: +86-577-88368280

Electronic Supplementary Information has 15 pages and 15 figures.

\section{Experimental section}

3-Aminobenzene-boronic acid was obtained from Shanghai Darui Fine Chemicals Co. Ltd. Neopentyl glycol and lauroyl chloride were obtained from Shanghai Aladdin Chemistry Co. Ltd. $L$-Phenylalanine, glycylglycine, ditertbutyl, dicarbonate, $L$-glutamine, $N$-hydroxysuccinimide (NHS), dicyclohexylcarbodiimide (DCC), 4-dimethylaminopyridine (DMAP) and 2-(1H-benzotriazole-1-yl)-1,1,3,3-tetra-methyluroniumtetrafluoroborate (TBTU) was obtained from Shanghai Energy Chemistry Co. Ltd. All solvents and reagents were commercially available and directly used without purification. 
General Techniques. ${ }^{1} \mathrm{H}$ and ${ }^{13} \mathrm{C}$ NMR spectroscopy were both performed on a Bruker-500 spectrometer operating at $500 \mathrm{MHz}\left({ }^{1} \mathrm{H} \mathrm{NMR}\right)$ and $125 \mathrm{MHz}\left({ }^{13} \mathrm{C}\right.$ NMR). TMS (tetramethylsilane) was used as an internal standard and DMSO- $d_{6}$ was used as the solvent. Mass spectrometric analysis was performed on Bruker microTOF-QII HR-MS analysis. Scanning electronic microscopy (SEM) images were taken on a NovaNanoSEM200 scanning electron microscope.Transmission electron microscope (TEM) images were taken on a JEM-2100F transmission electron microscope. HPLC were taken on Agilent 1120 type liquid instrument using inertsil ods-sp C18 chromatographic column. UV spectra were recorded on a UV2501PC spectrometer (Shimadzu). Rheological mechanics data were measured using Discovery HR-2.

Synthesis of Gelator. The synthesis process of gelator was showed in Scheme S1.

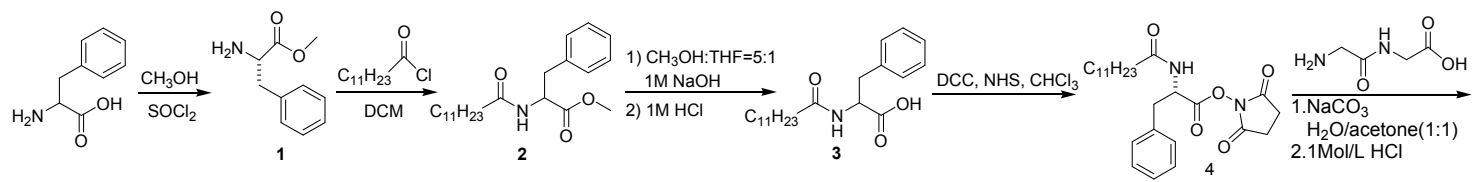

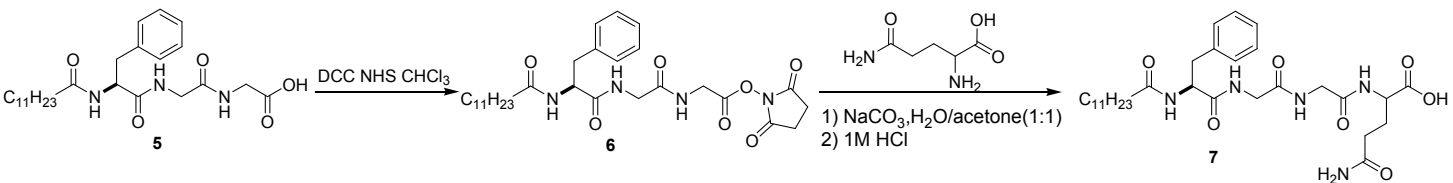

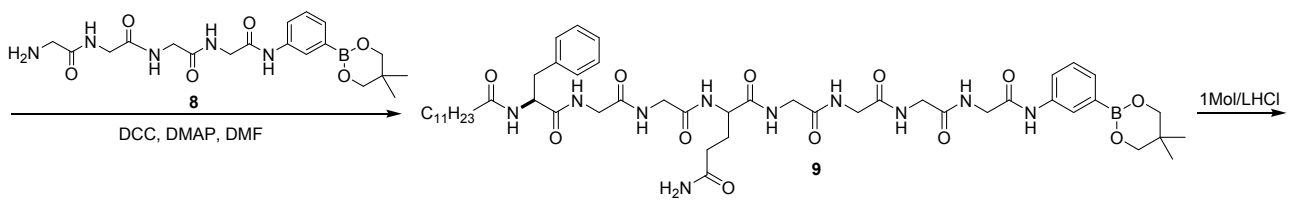

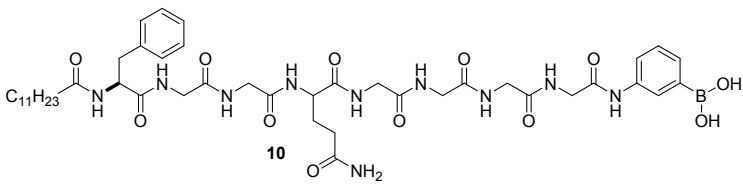

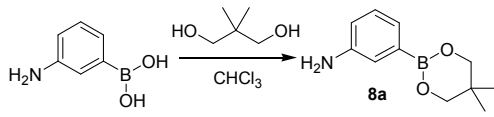

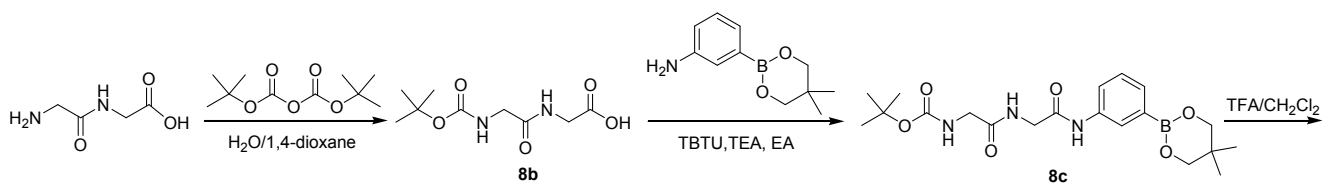

$$
\begin{aligned}
& \text { DCC, DMAP, DMF }
\end{aligned}
$$

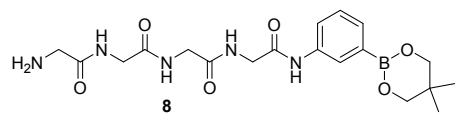

Scheme S1 Synthesis of gelator

Synthesis of compound $1.50 \mathrm{~mL}$ methanol in a $250 \mathrm{~mL}$ round flask was cooled to $0{ }^{\circ} \mathrm{C}$ firstly. Then, $4.0 \mathrm{~mL}$ thionyl chloride was added and stirred for $1 \mathrm{~h}$. $L$-Phenylalanine $(24 \mathrm{mmol})$ was 
added to the solution and heated to reflux for $10 \mathrm{~h}$. The solvent was evaporated under vacuum and diethyl ether was added to the residue. The mixture was filtrated and compound $\mathbf{1}$ was collected.

Synthesis of compound 2. Compound $1(21 \mathrm{mmol})$ was dissolved in dried $\mathrm{CH}_{2} \mathrm{Cl}_{2}$ and triethylamine $(6 \mathrm{~mL})$, cooled in ice bath. Then lauroyl chloride $(25.2 \mathrm{mmol})$ was added dropwise to the solution and stirred for overnight. The reaction mixture was filtered, and the filtrate was washed with saturated brine three times. The organic phase dried over anhydrous sodium sulfate. The residue was further purified by silica-gel chromatography (300-400 mesh) using uethyl acetate: petroleum ether $(\mathrm{v} / \mathrm{v}=1: 2)$ to obtain compound 2 .

Synthesis of compound 3. Compound $2(1.2 \mathrm{mmol})$ was dissolved in the mixture of $\mathrm{MeOH}$ and THF ( $/ / \mathrm{v}=5: 1,6 \mathrm{~mL}) .2 \mathrm{M} \mathrm{NaOH}(1.2 \mathrm{~mL})$ was added dropwise and the mixture was stirred for $2 \mathrm{~h}$. The solvent was evaporated under vacuum. The residue was cooled in ice bath, and $6 \mathrm{M} \mathrm{HCl} \mathrm{(5}$ $\mathrm{mL}$ ) was added dropwise. The residue was reprecipitated in ethyl acetate for three times to obtain compound 3 .

Compound 3, white solid, mp: 97.6-98.1 ${ }^{\circ} \mathrm{C} .{ }^{1} \mathrm{H}$ NMR (500 MHz, DMSO- $d_{6}$, TMS) $\delta$ 0.84-0.87 (t, $3 \mathrm{H}, \mathrm{J}=5.0 \mathrm{~Hz}$ ), 1.09-1.29 (m, 16H), 1.34-1.40 (m, 2H), 2.01-2.03 (t, 2H, J=5 Hz), 2.80-2.85 (dd, $1 \mathrm{H}, \mathrm{J}=5,15 \mathrm{~Hz}), 3.03-3.06(\mathrm{dd}, 1 \mathrm{H}, \mathrm{J}=10,15 \mathrm{~Hz}), 4.40-4.44(\mathrm{~m}, 1 \mathrm{H}), 7.17-7.27(\mathrm{~m}, 5 \mathrm{H})$, 8.07-8.09 (d, $1 \mathrm{H}, \mathrm{J}=15 \mathrm{~Hz}), 12.63(\mathrm{~s}, 1 \mathrm{H}) .{ }^{13} \mathrm{C}$ NMR (125 MHz, DMSO- $d_{6}$, TMS) $\delta 13.9,22.1$, 25.1, 28.7, 31.3, 35.0, 36.7, 53.2, 126.3, 128.0, 129.0, 137.8, 172.1, 173.2.

Synthesisofcompound 5. Compound 3 (694 mg, $2 \mathrm{mmol}$ ) and NHS (242 mg, $2.1 \mathrm{mmol})$ were dissolved in $30 \mathrm{~mL}$ of chloroform, and DCC (432 mg, $2.1 \mathrm{mmol}$ ) was added. After the mixture was stirred at room temperature for $12 \mathrm{~h}$, the resulting solid was filtered, and the filtrate was concentrated by rotary evaporation. The crude product 4 was used without purification. Glycylglycine (264 mg, $2 \mathrm{mmol}$ ) and $\mathrm{Na}_{2} \mathrm{CO}_{3}(424 \mathrm{mg}, 4 \mathrm{mmol}$ ) were dissolved in $20 \mathrm{~mL}$ of water, the solution of the crude compound 4 (dissolved in $20 \mathrm{~mL}$ acetone) was added, and the resulting reaction mixture was stirred at room temperature overnight. The reaction mixture was concentrated by rotary evaporation, and then $50 \mathrm{~mL}$ of water was added. The resulting solid was filtered, and the filtrate was acidified to $\mathrm{pH}=3$ and the resulting product was obtained by filtration. The residue was reprecipitated in ethyl acetate for three times to obtain compound $\mathbf{5}$.

Compound 5, white solid mp: $145.5-146.3{ }^{\circ} \mathrm{C} .{ }^{1} \mathrm{H}$ NMR (500 MHz, DMSO- $d_{6}$, TMS) $\delta 0.84-0.87$ $(\mathrm{t}, 3 \mathrm{H}, \mathrm{J}=5.0 \mathrm{~Hz}), 1.04-1.08(\mathrm{~m}, 2 \mathrm{H}), 1.17-1.37(\mathrm{~m}, 16 \mathrm{H}) 2.00-2.03(\mathrm{~m}, 2 \mathrm{H}), 2.72-2.77(\mathrm{dd}, 1 \mathrm{H}$, $\mathrm{J}=10,15 \mathrm{~Hz}), 3.02-3.05(\mathrm{dd}, 1 \mathrm{H}, \mathrm{J}=10,15 \mathrm{~Hz}) 3.69-3.81(\mathrm{~m}, 4 \mathrm{H}), 4.50-4.54(\mathrm{~m}, 1 \mathrm{H}), 7.14-7.18(\mathrm{~m}$, 1H), 7.24-7.25 (m, 4H), 8.02-8.04 (d, 1H, J=5.0 Hz), 8.06-8.09 (t, 1H, J=5.0 Hz), 8.24-8.26 (t, 1H, $\mathrm{J}=5.0 \mathrm{~Hz}), 12.57(\mathrm{~s}, 1 \mathrm{H}) .{ }^{13} \mathrm{C}$ NMR $\left(125 \mathrm{MHz}, \mathrm{DMSO}-d_{6}, \mathrm{TMS}\right) \quad \delta 13.9,22.1,25.1,28.4,28.7$, 28.8, 28.9, 29.0, 31.3, 35.2, 37.4, 40.6,41.8, 53.9, 126.1, 127.9, 129.1, 138.1, 169.0, 171.0, 171.7, 172.3. HRMS (ESI+) calcd for $\left(\mathrm{C}_{25} \mathrm{H}_{40} \mathrm{~N}_{3} \mathrm{O}_{5}\right)^{+}: 462.2959$; found: 462.2962 . 
Synthesis of compound 7. Compound 5 (922 mg, $2 \mathrm{mmol})$ and NHS (242 mg,2.1 mmol) were dissolved in $50 \mathrm{~mL}$ of chloroform, and DCC (432 mg, $2.1 \mathrm{mmol}$ ) was added. After the mixture was stirred for $12 \mathrm{~h}$ at room temperature, the resulting solid was filtered, and the filtrate was concentrated by rotary evaporation. The crude product 6 was used without purification. L-Glutamine(292mg, $2 \mathrm{mmol}$ ) and $\mathrm{Na}_{2} \mathrm{CO}_{3}(424 \mathrm{mg}, 4 \mathrm{mmol}$ ) were dissolved in $20 \mathrm{~mL}$ of water, the solution of the crude product 6 (dissolved in $20 \mathrm{~mL}$ acetone) was added, and the resulting reaction mixture was stirred at room temperature overnight. The reaction mixture was concentrated by rotary evaporation, and then $50 \mathrm{~mL}$ of water was added. The resulting solid was filtered off, and the filtrate was acidified to $\mathrm{pH}=3$ and the resulting product was obtained by filtration, and the residue was reprecipitated in ethyl acetate for three times to obtain compound 7. Compound 7, white solid, mp: $196.6-197.5{ }^{\circ} \mathrm{C} .{ }^{1} \mathrm{H}$ NMR (500 MHz, DMSO- $d_{6}$, TMS) $\delta 0.84-0.87$ $(\mathrm{t}, 3 \mathrm{H}, \mathrm{J}=5.0 \mathrm{~Hz}), 1.04-1.07(\mathrm{~m}, 2 \mathrm{H}), 1.16-1.32(\mathrm{~m}, 16 \mathrm{H}), 1.75-1.79(\mathrm{~m}, 1 \mathrm{H}), 1.88-1.94(\mathrm{~m}, 1 \mathrm{H})$, 2.01-2.07 (m, 4H), 2.74-2.79 (dd, 1H, J=10, 15Hz), 3.04-3.08 (dd, 1H, J=10, 15Hz), 3.71-3.77 (m, 4H), 3.92-3.95 (m, 1H), 4.51-4.55 (m, 1H), $6.67(\mathrm{~s}, 1 \mathrm{H}), 7.14-7.17(\mathrm{~m}, 1 \mathrm{H}), 7.21-7.26(\mathrm{~m}, 4 \mathrm{H})$, $7.38(\mathrm{~s}, 1 \mathrm{H}), 7.62-7.64(\mathrm{~m}, 1 \mathrm{H}), 8.21-8.31(\mathrm{~m}, 2 \mathrm{H}), 8.47-8.49(\mathrm{~m}, 1 \mathrm{H}) .{ }^{13} \mathrm{C}$ NMR $(125 \mathrm{MHz}$, DMSO- $d_{6}$, TMS) $\delta 13.9,22.1,25.1,28.4,28.7,28.8,28.9,29.0,29.1,31.3,31.9,35.2,37.4,42.1$, 42.3, 53.6, 53.9, 126.0, 127.9, 129.1, 138.2, 167.7, 169.1, 172.0, 172.3, 173.9, 174.6. HRMS (ESI+) calcd for $\left(\mathrm{C}_{30} \mathrm{H}_{48} \mathrm{~N}_{5} \mathrm{O}_{7}\right)^{+}: 590.3547$; found: 590.3548 .

Synthesis of compound 8: A mixture of 3-aminobenzeneboronicm acid (2.74 g, $20 \mathrm{mmol})$, neopentyl glycol(2.29 g, $22 \mathrm{mmol})$, and chloroform $(40 \mathrm{~mL})$ was stirred at room temperature overnight. The organic phase was separated, dried over anhydrous sodium sulfate, and filtered. The solvent was evaporated under vacuum, and the residue was reprecipitated in isopropanol to obtain compound $\mathbf{8 a}$.

1, 4-dioxane $(35 \mathrm{~mL})$ and $\mathrm{Et}_{3} \mathrm{~N}(11 \mathrm{~mL})$ were added to a solution of glycylglycine $(6.61 \mathrm{~g}, 50$ $\mathrm{mmol})$ in deionized water $(35 \mathrm{~mL})$, followed by adding Boc $_{2} \mathrm{O}(12.5 \mathrm{~mL}, 55 \mathrm{mmol})$. The solution was stirred for $24 \mathrm{~h}$ at room temperature, and then a solution of deionized water $(30 \mathrm{~mL})$ and EtOAc $(120 \mathrm{~mL})$ were added. The aqueous phase was washed with EtOAc $(120 \mathrm{~mL})$ again, then it was acidified with citric acid solids to $\mathrm{pH}$ 2.5. The aqueous phase was extracted with EtOAc (100 $\mathrm{mL}$ ) thrice. The organic phase was dried over anhydrous sodium sulfate, and evaporated under vacuum to obtain compound $\mathbf{8 b}$.

2-(1H-Benzotriazole-1-yl)-1, 1, 3, 3-tetra-methyluronium tetrafluoroborate (TBTU) (3.211 g, 10 mmol) was added to a mixture of compound $2(2.320 \mathrm{~g}, 10 \mathrm{mmol})$ and triethylamine $(2.8 \mathrm{~mL}, 20$ $\mathrm{mmol})$ in $40 \mathrm{~mL}$ ethyl acetate, then stirred at room temperature for $10 \mathrm{~min}$. Afterward compound 1 ( $2.46 \mathrm{~g}, 12 \mathrm{mmol}$ ) was added to the solution and stirred at room temperature for $24 \mathrm{~h}$. Then the mixture was filtered, and the solid was reprecipitated in dichloromethane/ethanol to obtain compound $\mathbf{8 c}$.

Compound 6c (4.0 g, $9.5 \mathrm{mmol})$ was dissolved in $\mathrm{CH}_{2} \mathrm{Cl}_{2}(7 \mathrm{~mL})$. TFA $(3.5 \mathrm{~mL})$ was added to the solution and stirred for $4 \mathrm{~h}$ at room temperature. The solution was evaporated under vacuum to 
remove $\mathrm{CH}_{2} \mathrm{Cl}_{2}$ and TFA. Then acetonitrile was added, and the mixture was filtered. The solid was reprecipitated in ethyl acetate to obtain compound $\mathbf{8 d}$.

Compound 8b (464mg, $2 \mathrm{mmol}$ ) and DCC (433mg, $2.1 \mathrm{mmol}$ ) were dissolved in dried DMF (30mL), then compound 8d (670 mg, $2.1 \mathrm{mmol}$ ) and DMAP (256 mg, $2.1 \mathrm{mmol}$ ) was added. After the mixture was stirred at room temperature overnight, the resulting solid was filtered off, and the filtrate was concentrated by rotary evaporation. Then the residue was reprecipitated in ethylacetate for three times to obtain compound $\mathbf{8 e}$.

Compound 8e $(1.1 \mathrm{~g}, 2 \mathrm{mmol})$ was dissolved in $\mathrm{CH}_{2} \mathrm{Cl}_{2}(20 \mathrm{~mL})$. TFA $(1.0 \mathrm{~mL})$ was added to the solution and stirred for $12 \mathrm{~h}$ at room temperature. The solution was evaporated under vacuum to remove $\mathrm{CH}_{2} \mathrm{Cl}_{2}$ and TFA. Then acetonitrile was added, and the mixture was filtered. The solid was reprecipitated in ethyl acetate to obtain compound $\mathbf{8}$.

Compound 8, brown solid, mp:232.9-233.8 ${ }^{\circ} \mathrm{C} .{ }^{1} \mathrm{H}$ NMR (500 MHz, DMSO- $d_{6}$, TMS) $\delta 0.96$ (s, $6 \mathrm{H}), 3.63(\mathrm{~s}, 2 \mathrm{H}), 3.75(\mathrm{~s}, 4 \mathrm{H}) 3.80-3.81(\mathrm{~d}, 2 \mathrm{H}, \mathrm{J}=5 \mathrm{~Hz}), 3.87-3.89$ (t, 4H, J=5Hz), 7.27-7.30 $(\mathrm{m}, 1 \mathrm{H}), 7.37-7.39(\mathrm{~d}, 1 \mathrm{H}), 7.69-7.70(\mathrm{~d}, 1 \mathrm{H}), 7.92(\mathrm{~s}, 1 \mathrm{H}), 8.07(\mathrm{~s}, 2 \mathrm{H}), 8.24(\mathrm{~m}, 1 \mathrm{H}), 8.34(\mathrm{~m}$, 1H), 8.67 (m, 1H), 9.87 (s, 1H). ${ }^{13} \mathrm{C}$ NMR (125 MHz, DMSO- $d_{6}$, TMS) $\delta$ 21.3, 31.4, 42.0, 42.6, $71.4,121.6,124.5,128.0,128.5,138.2,166.3,167.5,168.8,169.1$. HRMS (ESI + ) calcd for $\left(\mathrm{C}_{19} \mathrm{H}_{29} \mathrm{BN}_{5} \mathrm{O}_{6}\right)^{+}: 434.2220$; found: 434.2209 .

Synthesis of compound 9. Compound 7 (589mg, $1 \mathrm{mmol})$ and DCC (227 mg, $1.1 \mathrm{mmol})$ were dissolved in dried DMF (30mL), then compound 8 (476 mg, $1.1 \mathrm{mmol})$ and DMAP (134 mg, 1.1 mmol) was added. After the mixture was stirred at room temperature overnight, the resulting solid was filtered off, and the filtrate was concentrated by rotary evaporation. Then the residue was precipitated in ethyl acetate to obtain compoud 9.

Synthesis of compound 10: compound $9(1.0 \mathrm{~g}, 1.0 \mathrm{mmol})$ was added to $1 \mathrm{M} \mathrm{HCl}$ solution (50 $\mathrm{mL}$ ), and stirred for $24 \mathrm{~h}$ at room temperature. Then the solid was filtered and the residue was reprecipitated in ethyl alcohol for three times to obtain compound $\mathbf{1 0}$.

Compound 10, white solid, mp: 252.2-253.1 ${ }^{\circ} \mathrm{C} .{ }^{1} \mathrm{H}$ NMR (500 MHz, DMSO- $d_{6}$, TMS) $\delta$ 0.84-0.87 (t, 3H, J=5.0 Hz), 1.04-1.07 (m, 2H), 1.16-1.35 (m, 16H), 1.73-1.80 (m, 1H), 1.90-1.97 $(\mathrm{m}, 1 \mathrm{H}), 2.00-2.03(\mathrm{~m}, 2 \mathrm{H}), 2.10-2.13(\mathrm{t}, 1 \mathrm{H}, \mathrm{J}=5.0 \mathrm{~Hz}), 2.25-2.29(\mathrm{~m}, 1 \mathrm{H}), 2.72-2.77(\mathrm{dd}, 1 \mathrm{H}$, $\mathrm{J}=10,15 \mathrm{~Hz}), 3.03-3.06(\mathrm{dd}, 1 \mathrm{H}, \mathrm{J}=10,15 \mathrm{~Hz}), 3.75-3.79(\mathrm{~m}, 10 \mathrm{H}), 3.88-3.89$ (d, $2 \mathrm{H}, \mathrm{J}=5.0 \mathrm{~Hz})$, 4.22-4.32 (m, 1H), 4.51-4.55 (m, 1H), $6.78(\mathrm{~s}, 1 \mathrm{H}), 7.14-7.18(\mathrm{~m}, 1 \mathrm{H}), 7.22-7.28(\mathrm{~m}, 6 \mathrm{H})$, 7.48-7.49 (d, $1 \mathrm{H}, 5 \mathrm{~Hz}), 7.70-7.71(\mathrm{~d}, 1 \mathrm{H}, 5 \mathrm{~Hz}), 7.85(\mathrm{~s}, 1 \mathrm{H}), 8.00-8.10(\mathrm{~m}, 6 \mathrm{H}), 8.18-8.21(\mathrm{~m}, 3 \mathrm{H})$, 8.26-8.28 (m, $1 \mathrm{H}), 9.77(\mathrm{~s}, 1 \mathrm{H})$. HRMS $(\mathrm{ESI}+)$ calcd for $\left(\mathrm{C}_{44} \mathrm{H}_{66} \mathrm{BN}_{10} \mathrm{O}_{7}\right)^{+}$: 937.4945; found: 937.4957

\section{Gel preparation}

The gelators of compound $\mathbf{1 0}$ in PBS ( $\mathrm{pH}$ 7.4) were placed in closed glass vials and heated to form solutions. The solutions were cooled to room temperature to obtain gels. The critical gelation 
concentration (CGC) was determined by measuring the minimum amount of gelator to form a stable gel at $25{ }^{\circ} \mathrm{C}$. The xerogels for SEM and TEM were dried at room temperature in vacuum.

\section{Preparation of filtration and separation devices of LMWGs}

Taking a glass funnel, sealed the bottom of the tube using a small amount of absorbent cotton, then $1 \mathrm{~mL}$ heated solution of gelator in the phosphate buffer solution with different concentration was quickly moved to the glass funnel, the solution converted to gel soon at the room temperature, this simple filtration and separation devices was completed. A series of solutions of different compounds with different concentrations were prepared for evaluating the filtration and separation devices of LMWGs. $100 \mathrm{~mL}$ each solution was slowly add to the funnel with LMWGs as filling. The concentration of these solutions were detected before and after filtering material respectively.

\section{Detection of compounds used for separation}

The compounds used for separation were measured using HPLC, it was taken on Agilent 1120 type liquid instrument using inertsil ods-sp $\mathrm{C} 18$ chromatographic column. DOX $\mathrm{HCl}$ was detected at $28{ }^{\circ} \mathrm{C}$ with the wavelength of $495 \mathrm{~nm}$, the mobile phase was methanol: acetate buffer $(\mathrm{pH} \mathrm{3.4})=$ 55: 45. The phenformin was detected at $30{ }^{\circ} \mathrm{C}$ with the wavelength of $234 \mathrm{~nm}$, the mobile phase was methanol: phosphate buffer $(\mathrm{pH} 3.5)=25: 75$.

The cyanidin chloride was detected at $25^{\circ} \mathrm{C}$ with the wavelength of $520 \mathrm{~nm}$, the mobile phase was acetonitrile: water: phosphate $=12: 84: 4$.

Rhodamine 19 perchlorate was measured using ultraviolet spectrophotometer with the wavelength of $554 \mathrm{~nm}$.
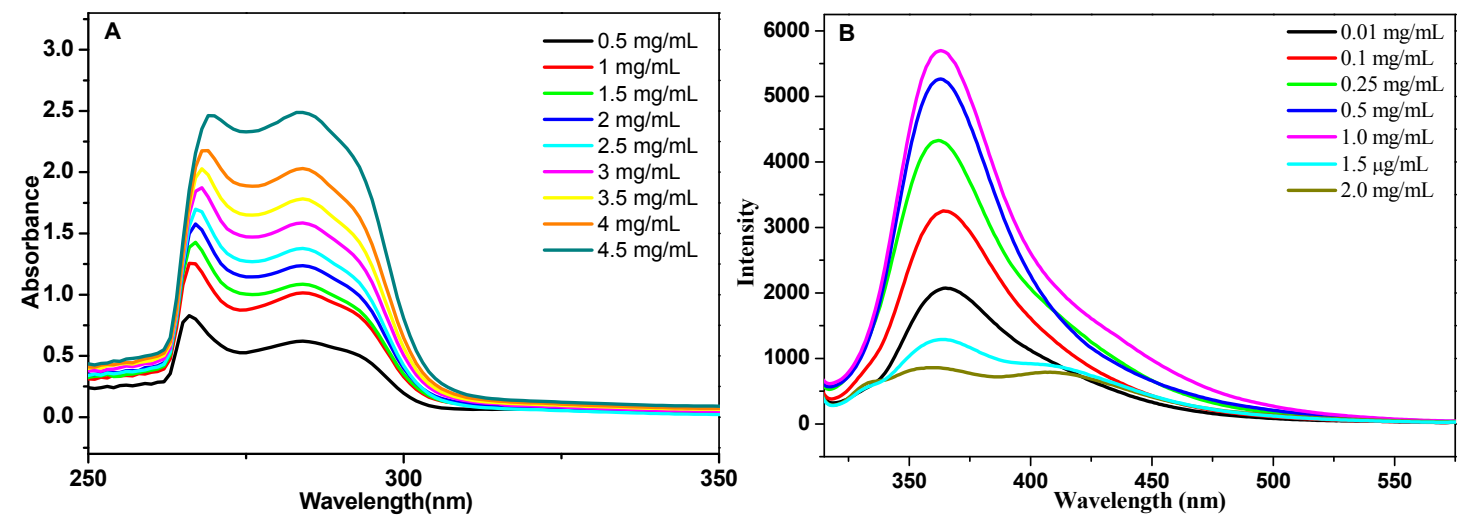

Figure S1. UV spectra (A) and fluorescence spectra (B) of gelator with different concentrations. 

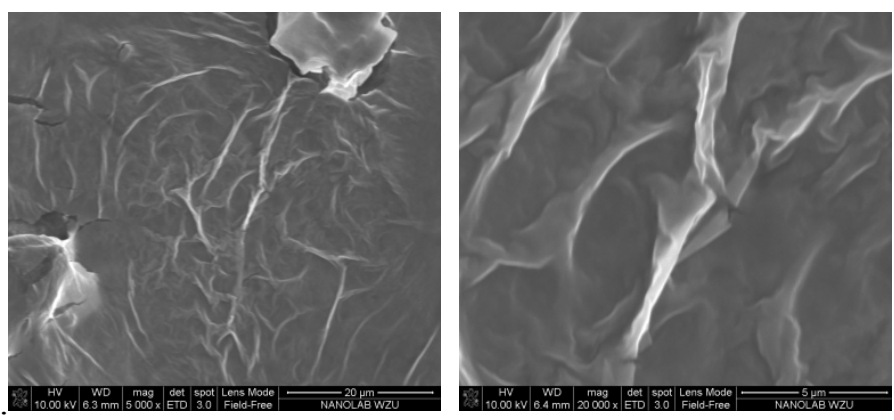

Figure S2. SEM images of the gel with the concentration of $15 \mathrm{mg} / \mathrm{mL}$.

$\stackrel{3}{1}$

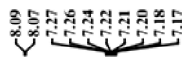

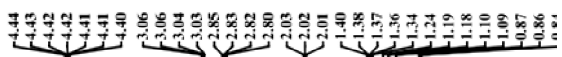
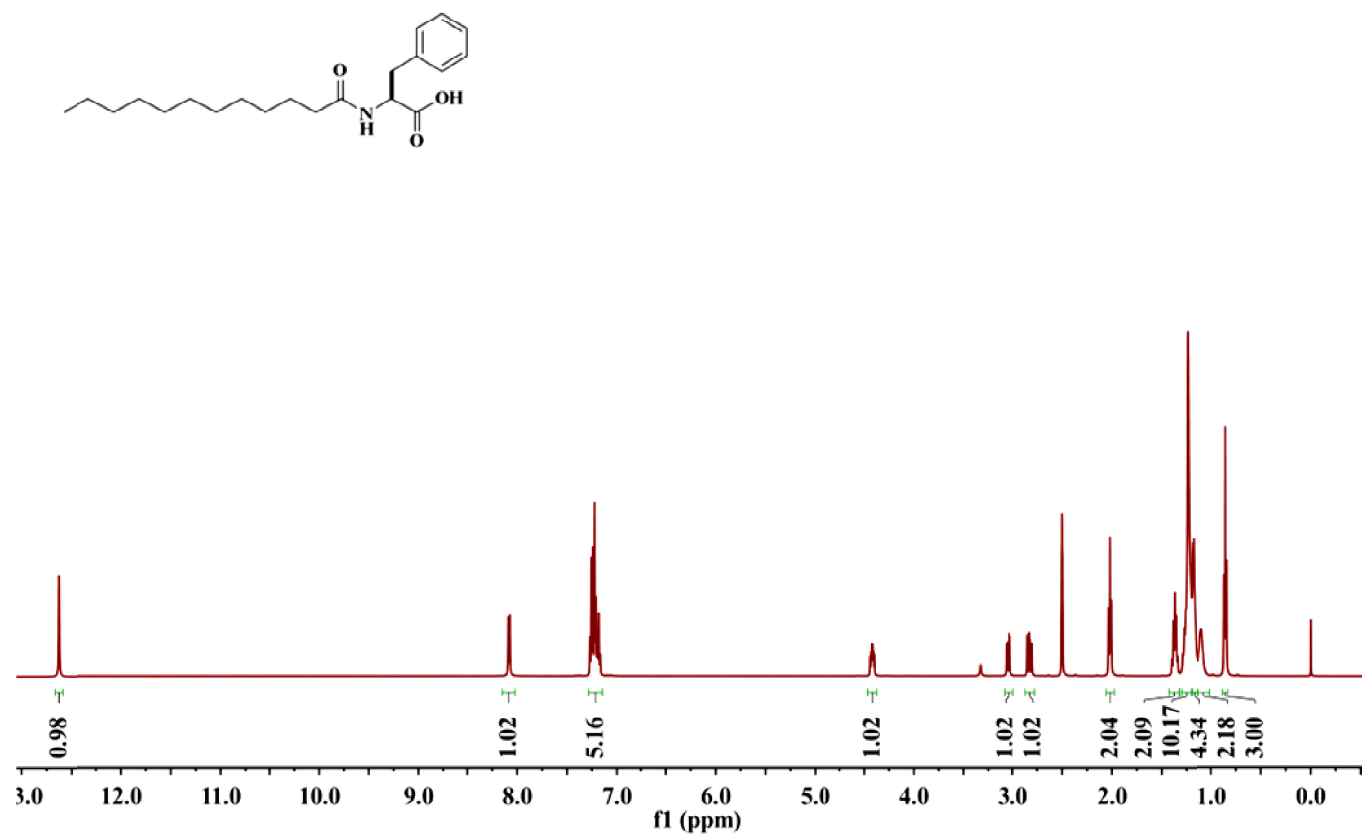

Figure S3. The ${ }^{1} \mathrm{H}$ NMR spectrum of compound 3 (DMSO- $d_{6}, 500 \mathrm{MHz}$ ) 


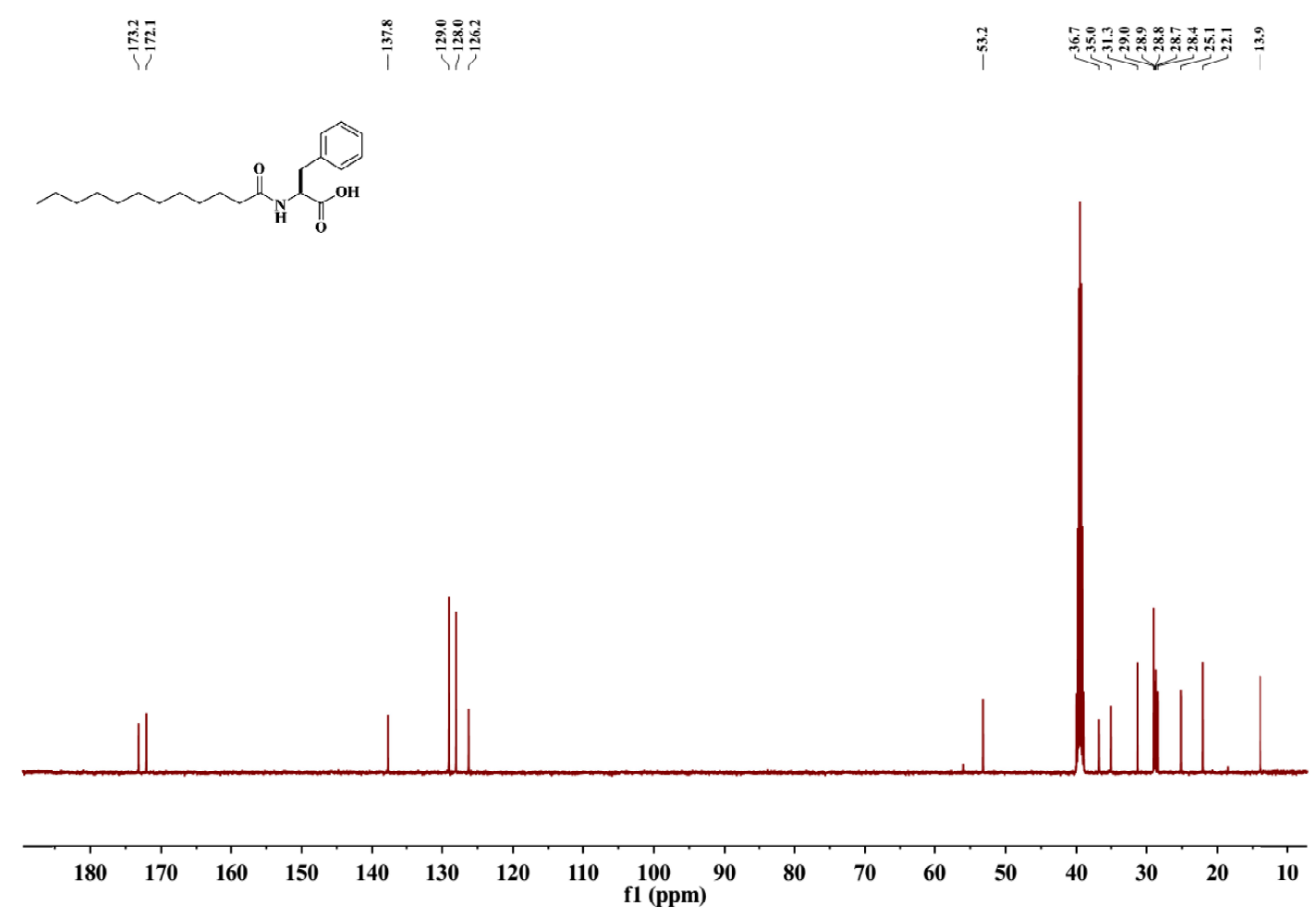

Figure S4 ${ }^{13} \mathrm{C}$ NMR spectrum of compound 3 (DMSO- $d_{6}, 125 \mathrm{MHz}$ )

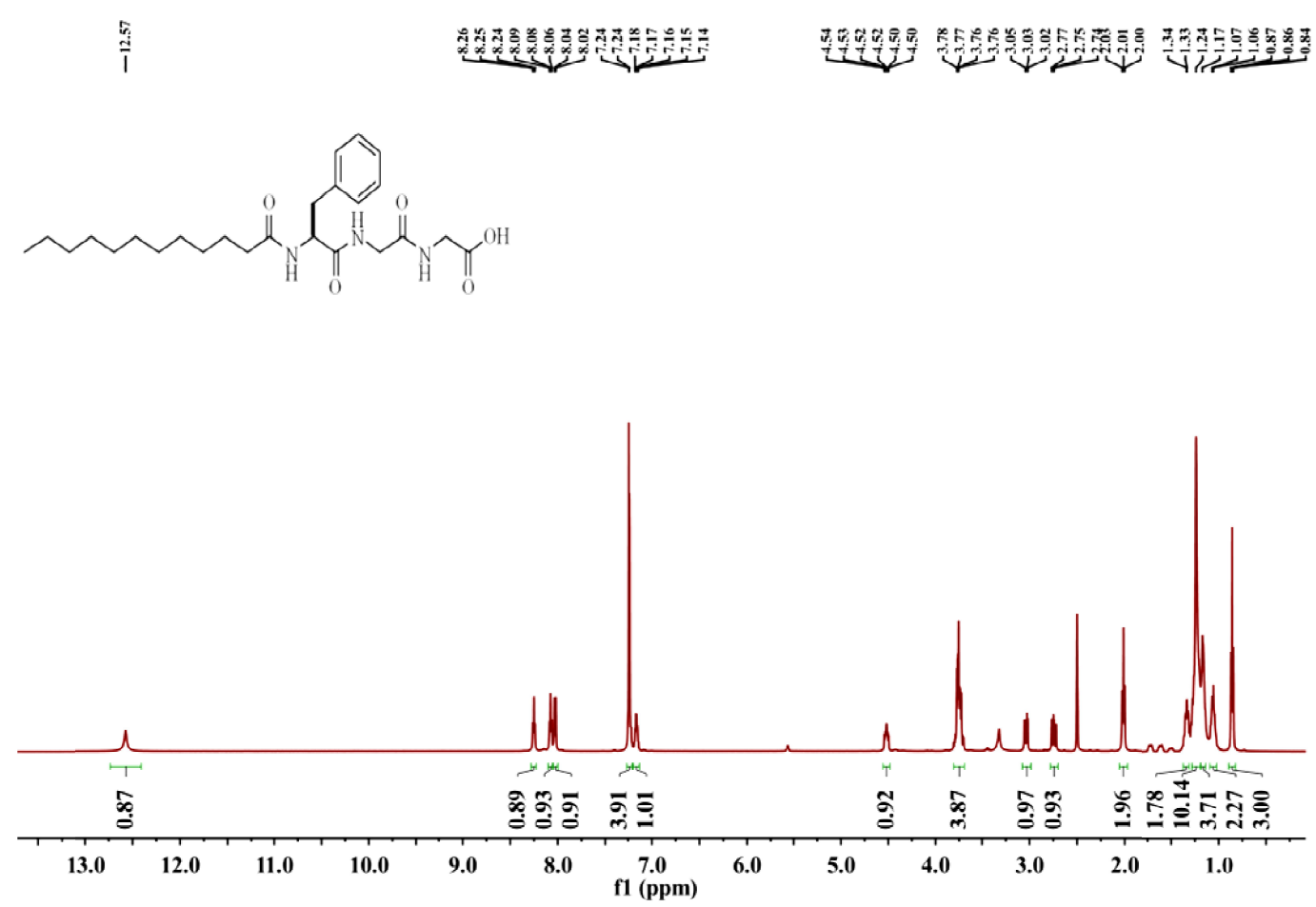

Figure S5. The ${ }^{1} \mathrm{H}$ NMR spectrum of compound 5 (DMSO- $\left.d_{6}, 500 \mathrm{MHz}\right)$ 


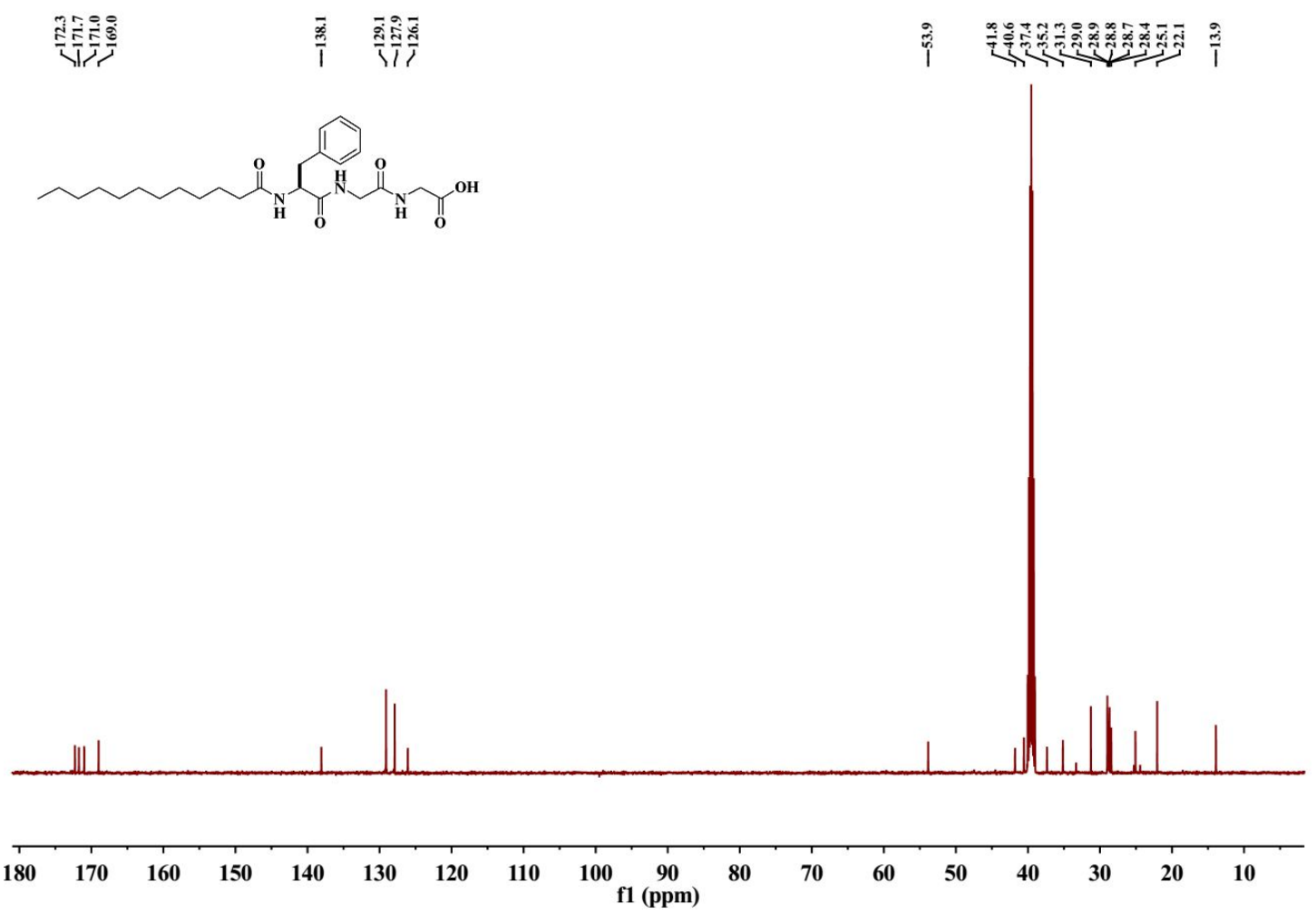

Figure S6 ${ }^{13} \mathrm{C}$ NMR spectrum of compound 5 (DMSO- $d_{6}, 125 \mathrm{MHz}$ )

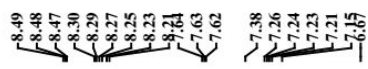
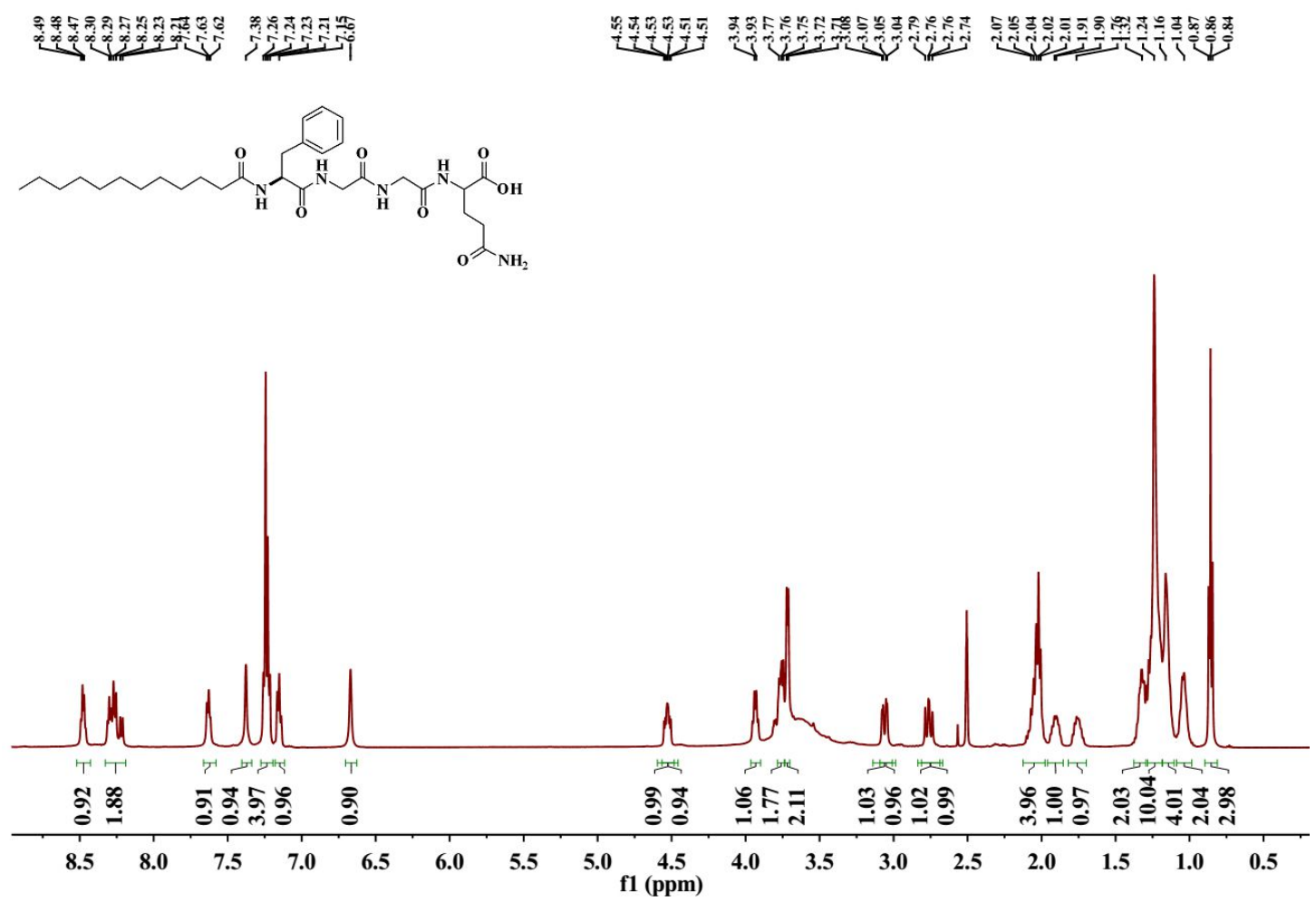

Figure S7. The ${ }^{1} \mathrm{H}$ NMR spectrum of compound 7 (DMSO- $\left.d_{6}, 500 \mathrm{MHz}\right)$ 


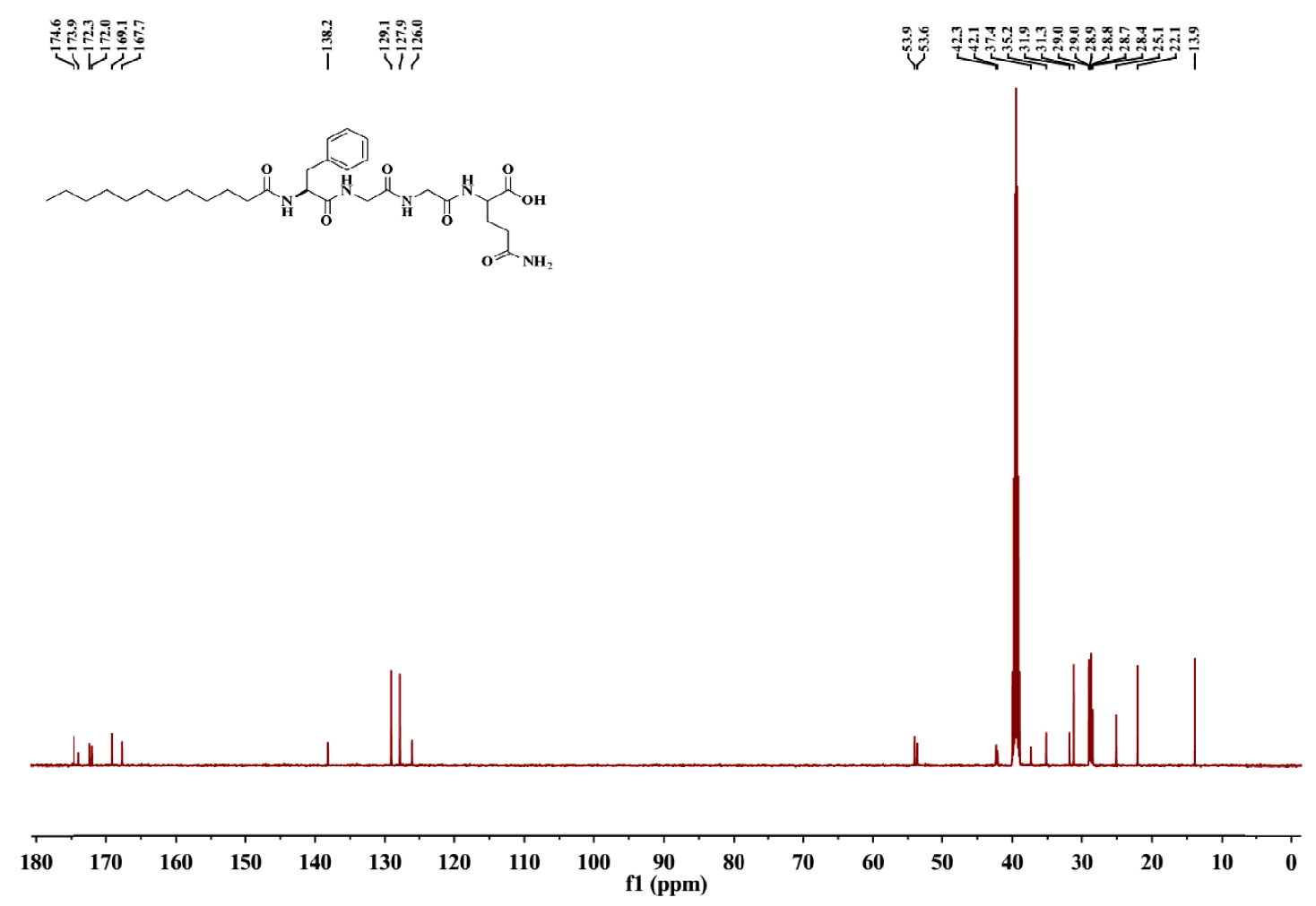

Figure S8. ${ }^{13} \mathrm{C}$ NMR spectrum of compound 7 (DMSO- $\left.d_{6}, 125 \mathrm{MHz}\right)$
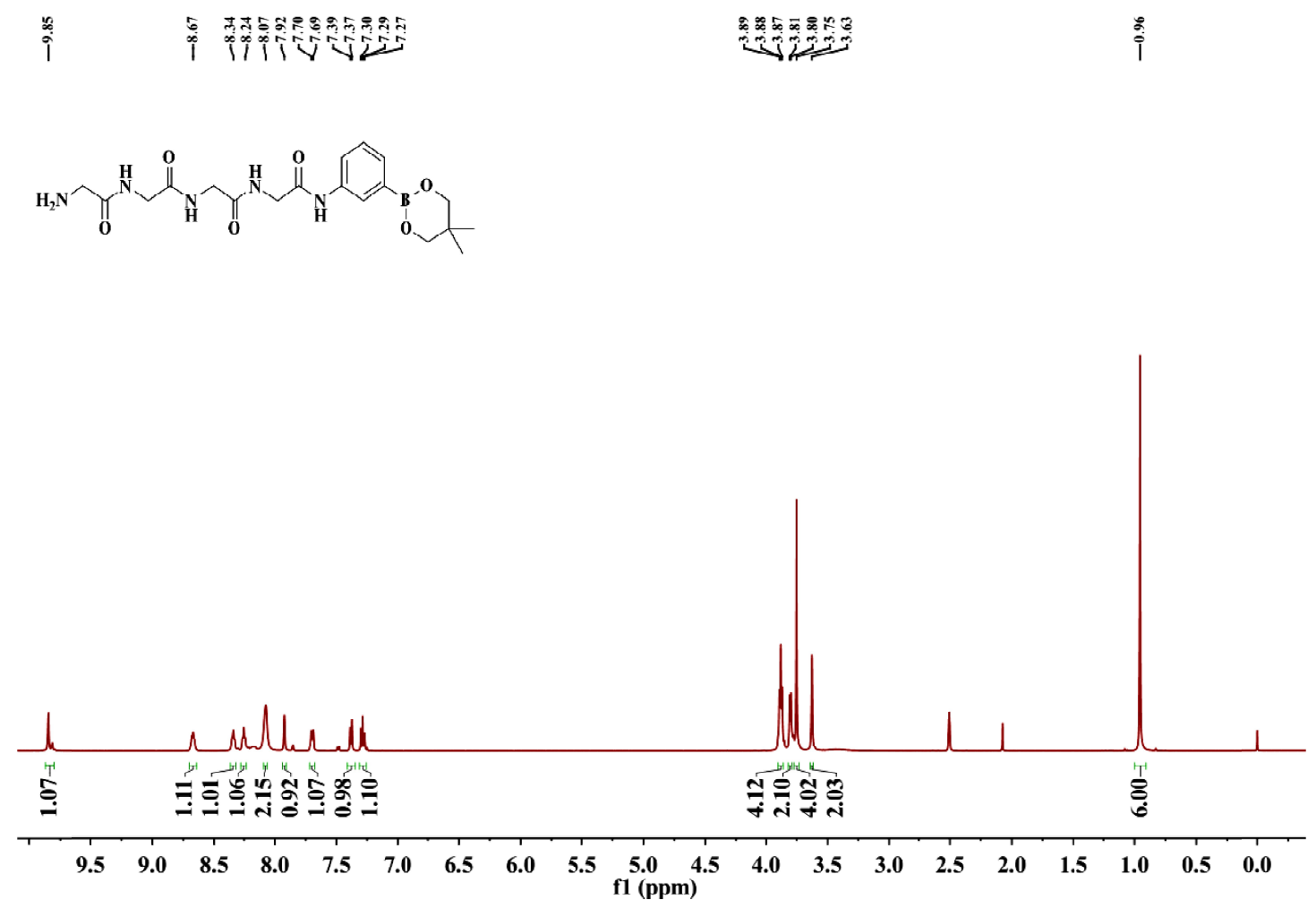

Figure S9. The 1H NMR spectrum of compound 8 (DMSO- $\left.d_{6}, 500 \mathrm{MHz}\right)$ 


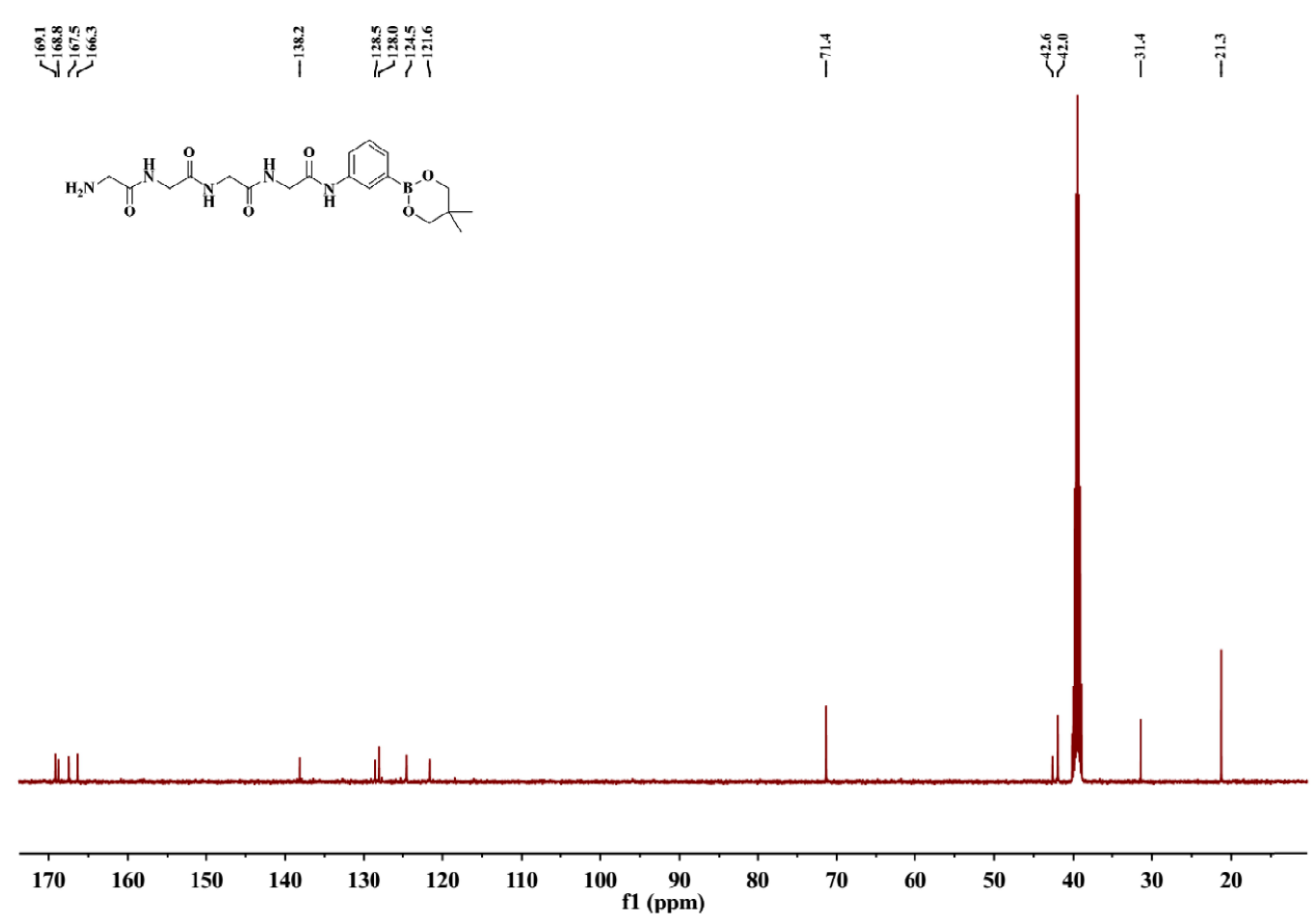

Figure S10. ${ }^{13} \mathrm{C}$ NMR spectrum of compound 8 (DMSO- $d_{6}, 125 \mathrm{MHz}$ )

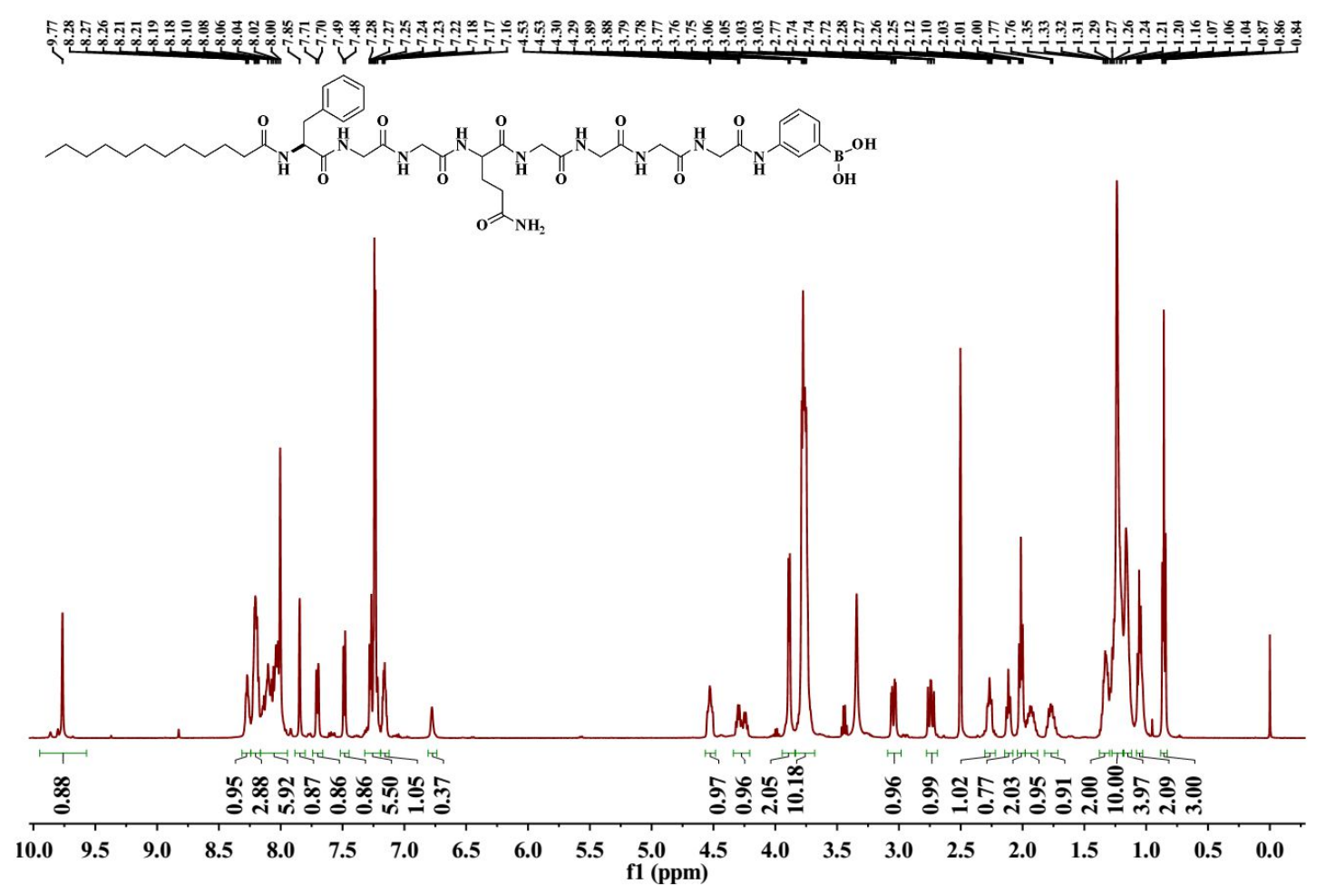

Figure S11. The ${ }^{1} \mathrm{H}$ NMR spectrum of compound 10 (DMSO- $\left.d_{6}, 500 \mathrm{MHz}\right)$ 

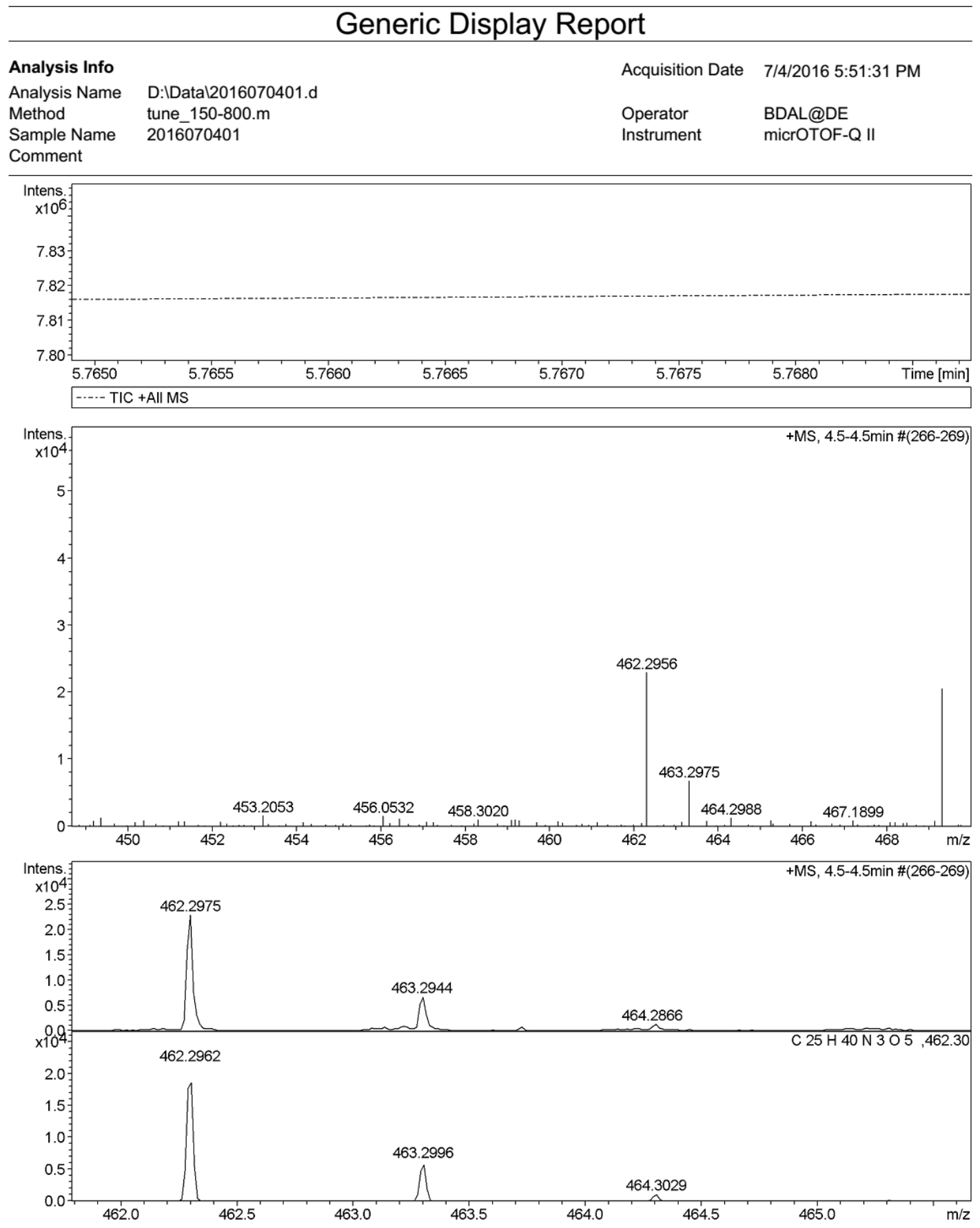

\begin{tabular}{llll}
\hline Bruker Compass DataAnalysis 4.0 & printed: & 7/15/2016 8:03:59 PM & Page 1 of 1
\end{tabular}

Figure S12. Mass spectra of compound 5 


\section{Generic Display Report}

\section{Analysis Info}

Analysis Name

tune_150-800.m

Operator

BDAL@DE

Sample Name

Instrument

micrOTOF-Q II

Comment
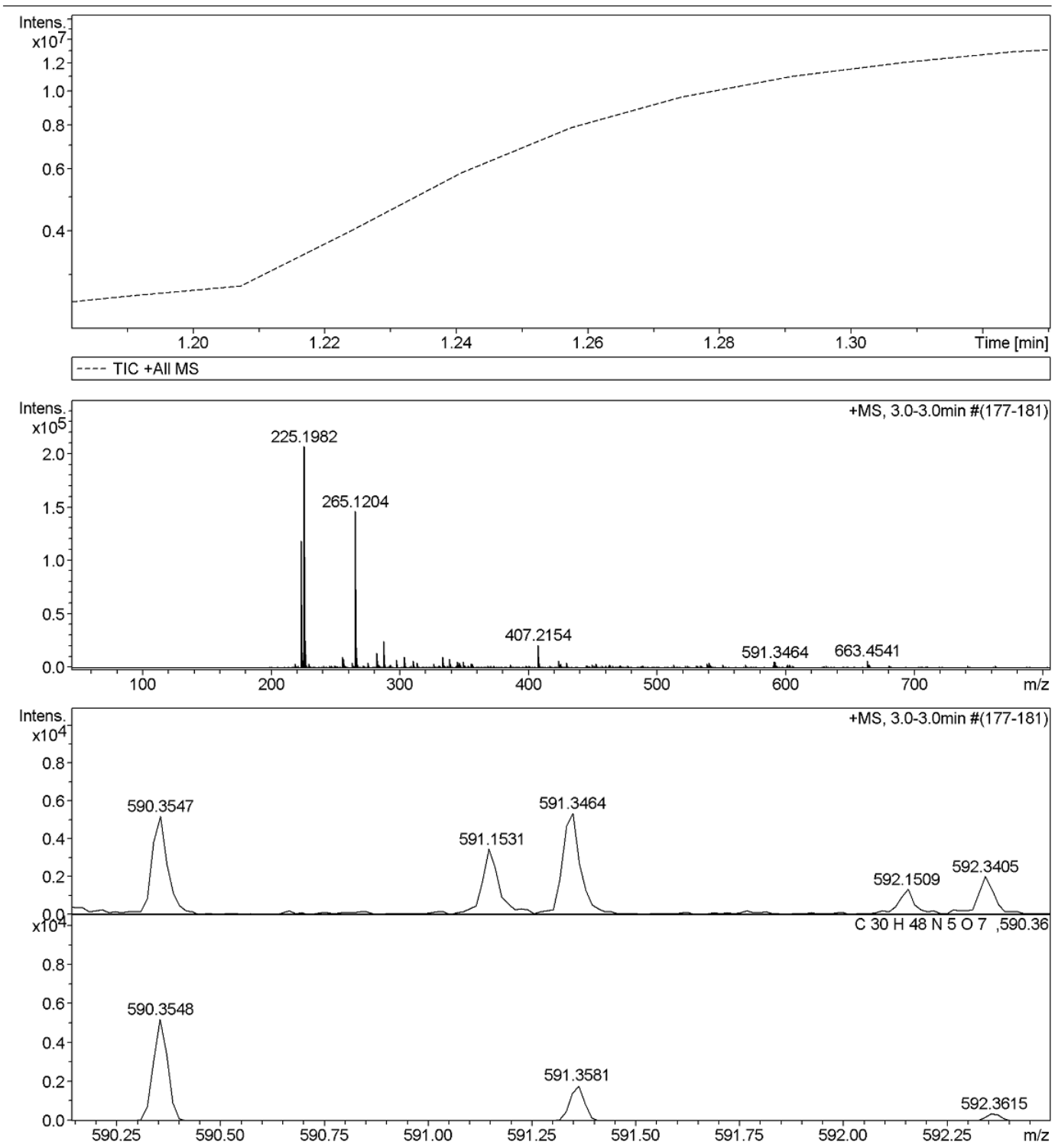

Bruker Compass DataAnalysis 4.0

printed: $\quad$ 4/6/2016 2:46:31 PM

Page 1 of 1

Figure S13. Mass spectra of compound 7 

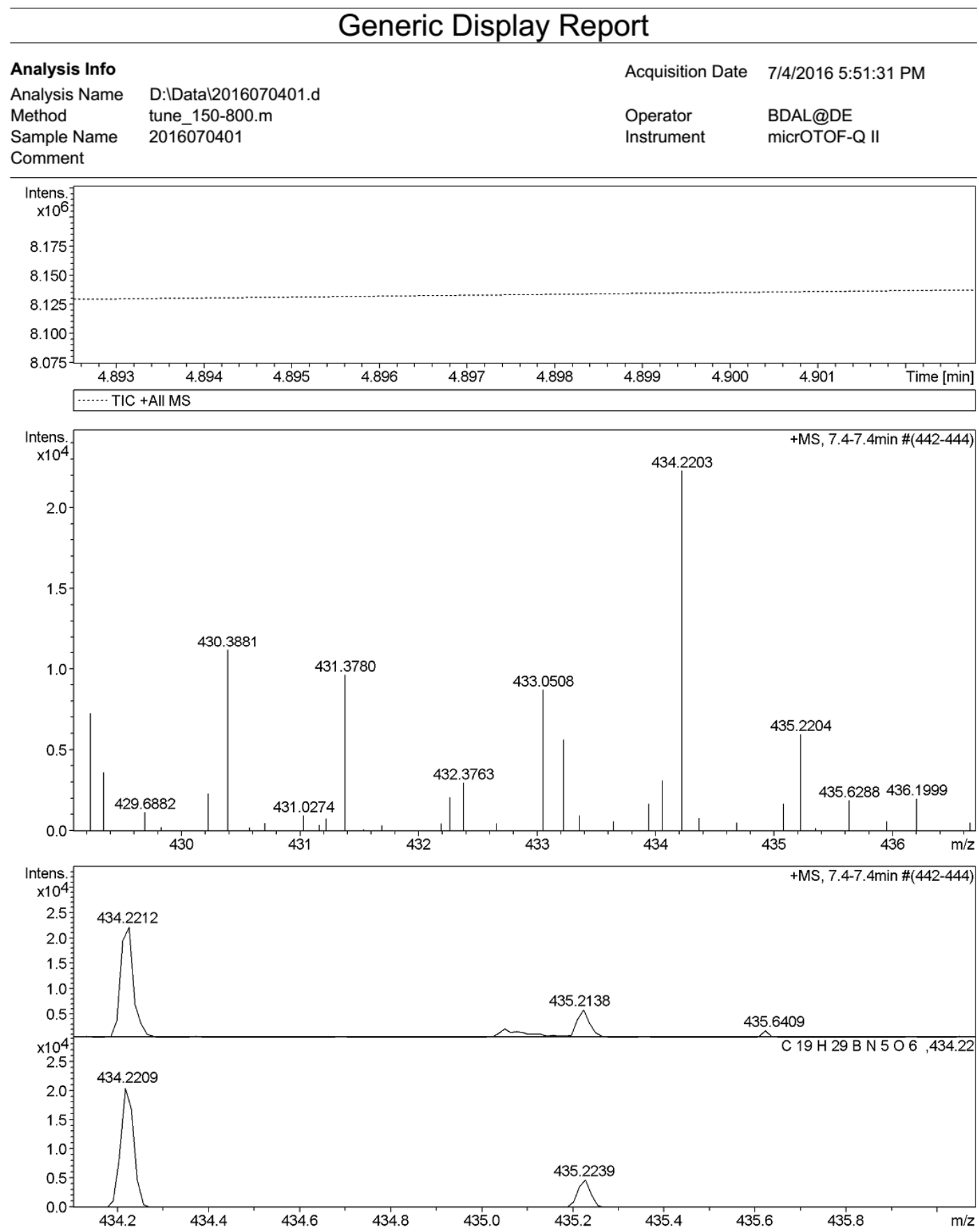

Figure S14. Mass spectra of compound 8 


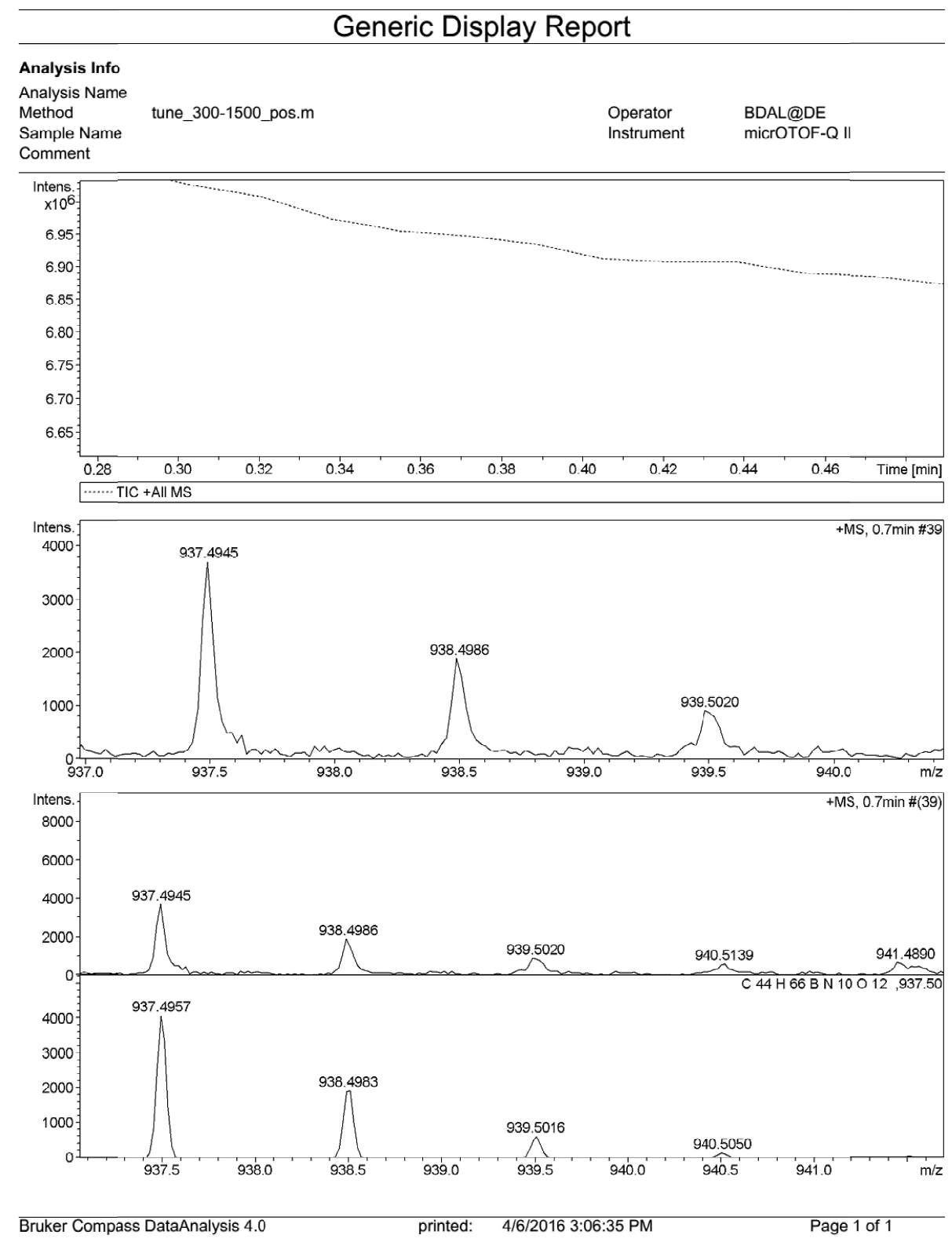

Figure S15. Mass spectra of compound 10 